\title{
Dehydration and Acute Weight Gain of Athletes Before Sport Competitions
}

\begin{abstract}
VELI VOLKAN GURSES'*, BAYRAM CEYLAN ${ }^{1}$, MUSTAFA SAKIR ${ }^{1}$, BILGEHAN BAYDIL ${ }^{1}$, HAMIDA AL HUSSEIN ${ }^{2}$, DANA BADAU ${ }^{2}$
${ }^{1}$ Kastamonu University, Faculty of Physical education and Sport, Street Org. Atilla Ates Pasa Cad 39 15-H, Street Kastamonu, Turkey

${ }^{2}$ University of Medicine and Pharmacy, Faculty of Medicine, 38 Gh. Marinescu Str., 540142, Targu Mures, Romania

The aim of this study was to evaluate the extent of acute weight gain, dehydration and rehydration in judo athletes before official competitions. The results showed that judo athletes are competing in dehydrated conditions and thus preventive measurements should be taken to prevent athletes' disadvantageous health circumstances related to acute weight gain and dehydration.
\end{abstract}

Keywords: acute weight gain, dehydration, real competition, weight loss, sport performance

Judo is a weight-classified combat sport where athletes try to throw the opponentonto his/her back or control them during the groundwork [1-3]. All judo athletes are required to achieve a specific body weight before competition. The aim of this classification is to make sure that competitions are held under equal conditions in terms of leverage, strength and agility. According to a survey carried out by Artioli et al. [4], judo athletes start losing weight at a very young age (generally before 15 years of age) and undergo rapid weight loss before the competition. Moreover, judo athletes often use such methods as increased amount of exercise, fluid restriction, skipping meals and gradual dieting. Rapid weight loss is doomed to eventually result in imperfect athletic performance and dehydration-related health problems [5]. The athletes' health status is very important for improving the physical capacity according with the requests of high sport performance $[6,7]$.

Primarily components of human urine are as follows: water $\mathrm{H} 2 \mathrm{O}: 91 \%$ to $96 \%$, with organic solutes including urea $\mathrm{H}_{2} \mathrm{NCONH}_{2}: 9.3 \mathrm{~g} / \mathrm{L}$ to $23.3 \mathrm{~g} / \mathrm{L}$, creatinine $\mathrm{C}_{4} \mathrm{H}_{7} \mathrm{~N}_{3} \mathrm{O}$ : $0.670 \mathrm{~g} / \mathrm{L}$ to $2.15 \mathrm{~g} / \mathrm{L}$, uric acid and trace amounts of enzymes, carbohydrates, hormones, fatty acids, pigments, mucins and inorganic ions such as sodium $\mathrm{Na}^{+}$: $1.17 \mathrm{~g} / \mathrm{L}$ to $4.39 \mathrm{~g} / \mathrm{L}$, potassium $\mathrm{K}^{+}: 0.750 \mathrm{~g} / \mathrm{L}$ to $2.61 \mathrm{~g} / \mathrm{L}$, chloride $\mathrm{Cl}: 1.87 \mathrm{~g} / \mathrm{L}$ to $8.4 \mathrm{~g} / \mathrm{L}$, magnesium $\mathrm{Mg}^{2+}$, and inorganic sulfur S2E: 0.163 to $1.80 \mathrm{~g} / \mathrm{L}$ [8-11]. Top of Form<smiles>NC(N)=O</smiles>

The specific gravity of adults generally ranges from 1.010 to 1.030 [14], its increases over normal values (hypersthenuria) having as associated factors: dehydration, excessive sweating, urinary tract infection, diarrhea, renal artery stenosis, hepatorenal syndrome, decreased blood flow such as kidney and excess vasopressin, etc. [15-18].

Vasopressin, identified as antidiuretic hormone (ADH), vasopressin arginine (AVP) or argipressin [19], are hormones released in the posterior pituitary gland as response to hypertonicity. AVP is a peptide prohormone having as main functions: increasing the amount of water without solvents reabsorbed back into the filtrate circulation in the nephron renal tubules, increasing peripheral vascular resistance and increasing arterial blood pressure by arteriolar constriction [4, 20-22].

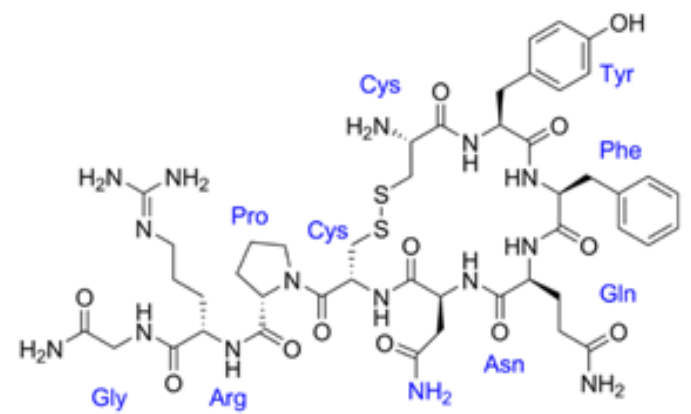

Fig. 2. Chemical structure of vasopressin with labeled amino acids [23]

Acute weight loss results in rigid dehydration. Negative physiological consequences that impair the athletic performance and also can damage one's health may appear as a result of extreme dehydration. Dehydration of more than $2 \%$ body mass is related to imperfect thermoregulatory function, increased cardiovascular stress and sometimes impaired aerobic performance [24]. Moreover, according to a review study by Cheuvront and Kenefick [25], more than $2 \%$ body mass loss via dehydration leads to decreased endurance performance and decreased strength and power performance.

In judo, official weigh-in is conducted approximately 15 $\mathrm{h}$ before the competitions and random weigh-in check is applied just before the first fights in the morning of the competition in order to control the weight gain of the athletes and it should be less than $5 \%$ of the athletes' weight category [26]. The time between the official weigh-in and competition should be enough for athletes to compensate hydration status as much as possible. As judo competitions are spread throughout a year, judo athletes are often exposed to acute weight gain following acute weight loss and dehydration. According to the literature, athletes lose weight mostly with dehydration $[21,27,28]$, which adversely affects their performance.

Given that judo is a very popular worldwide sport, acute dehydration and weight loss mean health-related injuries for a great number of athletes, becoming thus an important concern. Therefore, some preventive measurements should be taken in order to use prevalence of adverse 
weight loss methods. Moreover, judo athletes must be given enough time to rehydrate in order not to increase their likelihood unpleasant health issues both before and during the competition. As far as we are concerned, this is the first study which evaluates the volume of acute weight gain (AWG) and changes in hydration status in judo athletes before official competition. Thus, the aim of this study was to evaluate the extent of acute weight gain, dehydration and rehydration in judo athletes before official competition.

It is expected that this investigation may provide the guidelines to judo coaches who are the most influential persons on judo athletes in weight management [4], judo athletes and physicians that encourage safe participation and hinder judo athletes from consulting unhealthy weight loss methods.

\section{Experimental part \\ Methods}

A descriptive study was conducted based on repeatedmeasures design. To evaluate the magnitude of AWG and dehydration in a real competition environment, body mass and urinary samples for hydration status were determined approximately 15 and 2 hours before the competition in 31 judo athletes during 2018 Turkish Championship. Urinary samples were taken immediately before body mass measurements. Participants who could not provide a urine sample before weigh-in were excluded from the study. Participants followed their own routines and no encouragement was provided for consuming fluid between the two measurements. All measurements were carried out by the same researchers and the same procedures were repeated during the second measurement.

Seventeen male and fourteen female judo athletes voluntarily participated in this study, with the mean age $25.2 \pm 0.65$ years, height $1.77 \pm 0.01 \mathrm{~m}$, body mass $75.8 \pm$ $1.5 \mathrm{~kg}$, weight category $64.74 \pm 10.1 \mathrm{~kg}$, judo experience $9.68 \pm 1.9$ years, the values being expressed as mean \pm SD. All athletes signed a written and informed consent before the testing and all test procedures were approved by Karabuk University ethics committee. At least 4 years of judo experience was a criterion for participation in the study. The experimental procedures of our study were carried out in accordance with the mandatory principles of the ethic [29-31].

\section{Measurements}

-Acute weight gain: The official weigh-in was held $15 \mathrm{~h}$ before the competition. The athletes' actual body mass was measured with bioelectrical impedance device (Tanita MC-980, J apan) just before the official weigh-in. Also, $2 \mathrm{~h}$ before the competition all judo athletes were reweighted to determine the body mass. AWG was assessed as previously mentioned [5].
-Body composition evaluation: Body composition was evaluated with bioelectrical impedance device (Tanita MC980) only for descriptive purpose. Body fat percentage, muscle mass and total body water percentage (TBW) were recorded for each athlete.

- Hydration status evaluation: A urine sample was taken from each athlete immediately before each body mass measurement. The samples were placed in plastic cups and the specific gravity $\left(U_{s g}\right)$ was determined with a digital refractometer (ATAGO PÁL-10S, Japan). As soon as the urine samples were analyzed for $U_{s g^{\prime}}$ they were immediately disposed.

Statistical analyses SPSS 22 package program was used to analyze the data. Characteristics of the participants were determined with descriptive statistics. A repeated measures one-way analysis of variance was performed to detect significant differences between body mass and $U_{\text {si }}$. Pearson Correlation was performed to find the relationship between changes in body mass and $U_{\text {sg }}$. Significance was set at $p<0.05$ for all analysis. The size criteria for Pearson correlation coefficents was considered of 0.1 small, 0.3 medium and 0.5 large.

\section{Results and discussions}

In table 1 were presented the main results of the study: body mass, fat, muscle, TBW and $U_{\text {. }}$

Significant differences were found in dehydration levels of the athletes between official weigh-in and two hours before the competition $(F=4.53, p=0.04)$. Dehydration decreased from $1.027 \pm 0.006$ to $1.025 \pm 0.006$. Body mass increased from $65.42 \pm 9.53$ to $66.76 \pm 10.06$ indicating significant difference between the measurement times $(F=48.19, p=0.001)$. The mean value of AWG was found of $1.34 \pm 1.07 \mathrm{~kg}$ corresponding to $2.04 \%$ increase in body mass. A significant difference was observed in TBW values between official weigh-in and two hours before competition $(F=5.24, p=0.029)$ and it increased from $63.69 \pm 5.03$ to $64.98 \pm 6.13$.

Our results showed that $41.9 \%$ of the participants were seriously dehydrated $\left(U_{s q}>1.030\right), 45.2 \%$ were significantly dehydrated $(U>1.021)^{5 g}$ and $12.9 \%$ minimally dehydrated $\left(U_{s g}\right.$ between $\left.{ }^{51} 1.010-1.020\right)$. Furthermore, no athletes presented a well-hydrated $\left(U_{s}<1.010\right)$ status before the official weigh-in. When dehydration levels were measured 2 hours before the competition, $25.8 \%$ of the participants were found seriously dehydrated $\left(U_{s q}>1.030\right), 54.8 \%$ were significantly dehydrated $(\mathrm{U}>1.021)^{5 \mathrm{~s}}$ and $19.5 \%$ minimally dehydrated ( $U_{s}$ between $\left.1.010-1.020\right)$, while no athletes presented a well-hydrated status. Moderate negative correlation was found in changes between body mass and $U_{s q}(r=-0.39, p=0.029)$.

${ }^{\text {s9 }}$ To the best of our knowledge, the results of this study are the first to investigate and interpret AWG and dehydration status of judo athletes. The main findings of the present study were as follows: (1) dehydration levels

\begin{tabular}{|c|c|c|c|c|c|c|c|}
\hline \multirow[t]{2}{*}{ Items } & \multirow[t]{2}{*}{ Timing } & \multirow[t]{2}{*}{ Mean } & \multirow[t]{2}{*}{ SD } & \multicolumn{2}{|c|}{ One Sample test } & \multicolumn{2}{|c|}{ Paired Samples Test } \\
\hline & & & & $\mathrm{t}$ & $\mathrm{p}$ & $\mathrm{t}$ & $\mathrm{p}$ \\
\hline \multirow{2}{*}{$\begin{array}{l}\text { Body mass } \\
(\mathrm{kg})\end{array}$} & before $15 \mathrm{~h}$ & 65.42 & \pm 9.53 & 38.19 & $<0.0001$ & \multirow{2}{*}{-6.94} & \multirow{2}{*}{0.000} \\
\hline & before $2 \mathrm{~h}$ & 66.76 & \pm 10.06 & 36.94 & $<0.0001$ & & \\
\hline \multirow[t]{2}{*}{ Fat (kg) } & before $15 \mathrm{~h}$ & 13.67 & \pm 8.29 & 9.18 & $<0.0001$ & \multirow{2}{*}{-2.90} & \multirow{2}{*}{0.007} \\
\hline & before $2 \mathrm{~h}$ & 14.66 & \pm 7.86 & 10.37 & $<0.0001$ & & \\
\hline \multirow[t]{2}{*}{ Muscle (kg) } & before $15 \mathrm{~h}$ & 53.58 & \pm 8.67 & 34.40 & $<0.0001$ & \multirow{2}{*}{-1.17} & \multirow{2}{*}{0.250} \\
\hline & before $2 \mathrm{~h}$ & 53.91 & \pm 8.42 & 35.60 & $<0.0001$ & & \\
\hline \multirow[t]{2}{*}{ TBW } & before $15 \mathrm{~h}$ & 64.98 & \pm 6.13 & 59.01 & $<0.0001$ & \multirow{2}{*}{2.13} & \multirow{2}{*}{0.041} \\
\hline & before $2 \mathrm{~h}$ & 63.68 & \pm 5.03 & 70.39 & $<0.0001$ & & \\
\hline \multirow[t]{2}{*}{$\mathrm{U}_{\text {sg }}$} & before $15 \mathrm{~h}$ & 1.02 & \pm 0.00 & 854.16 & $<0.0001$ & \multirow{2}{*}{2.13} & \multirow{2}{*}{0.041} \\
\hline & before $2 \mathrm{~h}$ & 1.02 & $=.00$ & 911.42 & $<0.0001$ & & \\
\hline
\end{tabular}

Table 1 DESCRIPTIVE STATISTIC.

\footnotetext{
$t$-Student $t$ values; $p$ - level of probability.
} 
of the judo athletes decreased from official weigh-in to $2 \mathrm{~h}$ before the competition; (2) body mass increased from official weigh-in to 2 hours before the competition; (3) the percentage of TBW increased from official weigh-in to $2 \mathrm{~h}$ before the competition; (4) most athletes were seriously dehydrated during the official weigh-in, while a minimal dehydration was found in a minority of them; (5) most athletes were significantly dehydrated 2 hours before the competition, while a minority presented minimal dehydration; (6) none of the athletes presented a wellhydrated status before the competition; (7) a moderate negative correlation was found in changes between body mass and $U$

Our findingis regarding the AWG $(1.34 \pm 1.07)$ are similar with the results of previous investigations published by Artioli et al in $2010(1.6 \pm 1.4 \mathrm{~kg})$, respectively Berkovich et al in $2016(1.4 \pm 1.0 \mathrm{~kg})[4,21]$. Jetton et al (2013) and Kons et al (2017) reported an AWG after official weigh-in of $2.6 \pm 2 \mathrm{~kg}$ and $3.4 \pm 2.2 \mathrm{~kg}$ respectively being higher than our results $[5,32]$. The AWG determined by Jetton et al (2013) at the official weigh-in and 2 hours before the competition, was found two times higher than our results (AWG percentage $-4.4 \%$ of the body weight) [5]. An association between the amount of weight loss and success in real competitions was reported by other authors who investigated the wrestlers [26,33-34]. How ever, Horswill etal. [34], suggested no difference in performance related to higher amount of weight loss. In accordance with the above-mentioned results and findings, it can be suggest that judo and wrestling athletes present AWG following rapid weight loss having unhealthy weight loss behaviors.

The hydration status of the judo athletes was determined by means of $U_{s g}$ founding a significant decrease from $1.027 \pm 0.006$ to ${ }^{\circ p^{\prime}} .025 \pm 0.006$ between the official weighin to just before the competition. Our results were similar with those reported by Jetton et al [5], both studies suggesting that athletes were not in a hydrated status before the real competition.

The rapid weight loss methods have been reported to be generally based on caloric restriction and dehydration techniques $[4,21,26]$. Therefore, it is inevitable that rapid weight loss results in dehydration-related health problems and impaired athletic performance. Our results on the degree of dehydration showed that no athlete participating in this study could compensate water loss between the official weigh-in and the competition presenting the $U$ level $<1.010$, which may lead to impaired performance during the competition. This idea can be supported by Yýldýrým findings [35], stating negative correlation between testosterone and dehydration and positive correlation between cortisol concentration and dehydration state.

\section{Conclusions}

Significant changes were found in body weight and dehydration state of the athletes, between the official weigh-in and two hours before the competition suggesting that athletes underwent serious rapid weight loss and dehydration followed by AWG, but not enough hydration. It was stated that $54.8 \%$ of the athletes were significantly dehydrated $\left(U_{s 0}>1.021\right) 2$ hours before the competition, indicating that athletes competed in a dehydrated status.

\section{References}

1.CEYLAN, B., BALCI, S.S., International Journal of Engineering Sciences and Management, 2, no.3, 2017, p. 91-94

2.MANOLACHI, V., Gymnasium, 16, no. 1, 2015, p. 1-14
3.FRANCHINI, E., DEL VECCHIO, F.B., MATSUSHIGUE, K.A., ARTIOLI, G.G., Sports Med., 41, no. 2, 2011, p. 147-66

4.ARTIOLI, G.G., FRANCHINI, E., NICASTRO, H., STERKOWICZ, S., SOLYS, M.Y., LANCHA, A. H., J. Int. Soc. Sport Nutr., 7, no. 15, 2010, p. 1-5

5.JETTON, A.M., LAWRENCE, M.M., MEUCCI, M., HAINES, T.L., COLLIER, S.R., MORRIS, D.M., UTTER, A.C., J Strength Cond Res, 27, no. 5,2013, p. 1322-1326

6.BADAU, D., BADAU, A., PARASCHIV, F., ROGOZEA, L., AL HUSSEIN, H., BRINZANIUC, K., Rev. Chim. (Bucharest), 69, no. 2, 2018, p. 332336

7.GORUCU, A., TOKAY, B., BADAU, A., Physical education of students, 21, no. 4, 2017, p. 152-157

8.PRICOP, C., VACAROIU, I.A., RADULESCU, R., ANDONE, D., PUIA, P., Rev. Chim. (Bucharest), 69, no. 2, 2018, p. 375-278

9.VESCAN, A.T., OSZ, B.E., MAIER, A., IMRE, S., ORMENISAN, A., HANCU, V., VARI, C.E., Rev. Chim. (Bucharest), 68, no. 10, 2017, p. 2284-2288

10.NAGY, E.N., TILINCA, M.C., IACOB, A., ORMENISAN, A., FAZAKAS, Z., BARBU, H.M., KOLCSAR, M., MAIER, A.C., VIDA, A.O., ORSOLYA, M., Rev. Chim. (Bucharest), 68, no. 4, 2017, p. 680-682.

11 .** https://www.thoughtco.com/the-chemical-composition-of-urine603883

12.*** https://en.wikipedia.org/wiki/Urine

13.*** https://ww w.quora.com/W hat-is-the-chemical-composition-ofurine

14.ROSE, C., PARKER, A., JefFERSON, B., CARTMELL, E., Critical Reviews in Environmental Science and Technology., 45, no. 17, 2015, p. 1827-1879

15.GEORGESCU, S.R., ENE, C.D., NICOLAE, I., MITRAN, M., MUSETESCU, A., MATEI, C., RUSU, L.C., TAMPA, M., Rev. Chim. (Bucharest), 68, no. 5, 2017, p. 1103-1108

16.RILEY, R.S., MCPHERSON, R.A., 23rd ed. St Louis, MO: Elsevier Saunders; 2017, chap 28

17.FOGAZZI, G.B., GARIGALI, G., 5th ed. Philadelphia, PA: Elsevier Saunders; 2015, chap 4

18.ARMSTRONG, L.E., SOTO, J .A., HACKER, F.T., CASA, D.J ., KAVOURAS,

S.A., MARESH, C.M., Int. J. Sport Nutr., 8, 1998, p. 345-355.

19.ANDERSON, D.A., 32nd ed. Elsevier, 2012. ISBN 978-1-4160-6257-8

20.HONCERIU, C., CIOBICA, A., STOICA, B., CHIRAZI, M., PADURARIU,

M. Rev. Chim. (Bucharest), 67, no. 11, 2016, p. 2246 - 2249

21.BERKOVICH, B.E., ELIAKIM, A., NEMET, D., STARK, A.H., SINAI, A.H., Int J Sport Nutr Exerc metab., 26, no. 3, 2016, p. 276-84

22.LIM, M.M., YOUNG, L.J., Neuroscience, 125, no. 1, 2004, p. 35-45 23.*** https://en.wikipedia.org/wiki/Vasopressin

24.KENEFICK, R.W., Sports Med., 48, (Suppl 1), 2018, p. 31-37

25.CHEUVRONT, S.N., KENEFICK, R.W., Compr. Physiol.,4, no. 1, 2014, p. $257-85$

26.*** https://www.ijf.org/

27.ALDERMAN, B.L., LANDERS, D.M., CARLSON, J., SCOTT., J. R., Med

Sci Sports Exerc., 36, no. 2, 2004, p. 249-252

28.KORDI, R., ZIAEE, V., ROSTAMI, M., WALLACE, W.A., Sports Med Arthrosc Rehabil Ther Technol. 3, no. 4, 2011, p. 1-7

29.CHIRITA, P., ASAFTEI, I.V., SANDU, I., SARBU, L.G., LUPU, V.V., Rev. Chim. (Bucharest), 68, no. 1, 2017, p. 147-150

30.ALBU, R.G., MANDRU, L., SUCIU, T., 30 $30^{\text {th }}$ International-BusinessInformation-Management-Association Conference, Vision 2020: Sustainable Economic Development, Innovation Management and Global Growth, Madrid, Spain, 2017, p. 203-211

31.TOADER, E., TOADER, T., Revista Romana de Bioetica, 10, no. 3, 2012, p. 66

32.KONS, R.L., DA SILVA ATHAYDE, M., FOLLMER, B., DETANICO, D., Human Movement, 18, no. 2, 2017, p. 49-55

33.WROBLE, R.R., MOXLEY, D.P., Med Sci Sports Exerc. 30, no.4, 1998, p. 625-628

34.HORSWILL, C.A., SCOTT, J.R., DICK, R.W., HAYES, J ., Med Sci Sports Exerc. 26, no. 10, 1994, p. 1290-1294

35.YILDIRIM, I., Am J Med Sci., 350, no. 2, 2015, p. 103-108 